\title{
Instruction and Outreach for Transfer Students: A Colorado Case Study
}

\section{Linds West Roberts, Megan E. Welsh, and Brittany Dudek}

Studies of transfer student success abound in higher education, yet few studies examine the role that academic libraries play in students' transitions. This study explores the academic library services offered to transfer students in Colorado through a survey of librarians. What are barriers to offering these services? How do library professionals perceive instruction and outreach to transfer students? Results show differences between attitudes and practice, even within the same institution, and suggest opportunities for future collaboration among two-year and four-year academic libraries in Colorado. The article discusses these findings in the context of findings from New York and Ohio studies, suggesting that academic libraries need greater awareness of, and services for, transfer students.

\section{Introduction}

Transfer students face individual challenges related to retention and persistence that are not always well understood or well supported by institutions of higher education. Although certain needs extend across populations to all students, transfer students have distinctive needs that, when not met, could become challenges to their successful transition to a new educational setting. Transfer students may be more likely to come from underrepresented backgrounds, be older, have full-time or part-time jobs, support dependents, be financially independent, and so on, and these demographic characteristics may impact their transition to their new institution. ${ }^{1}$ If colleges and universities are not prepared to meet the needs of students who are outside the "traditional" college student profile, then transfer students may experience obstacles at their new institution.

It is common for students to transfer from one institution to another or even among several institutions. Peter and Cataldi found that 59 percent of students graduating in the 1999/2000 cohort of the Baccalaureate and Beyond Longitudinal Study from the National Center for Education Statistics (NCES) attended more than one institution, and 24 percent attended three or more institutions. ${ }^{2}$ More recently, an NCES report identified 35 percent of first-time students in

\footnotetext{
${ }^{*}$ Linds West Roberts is Assistant Professor, Education Librarian, and Megan E. Welsh is Assistant Professor, Interdisci-plinary Arts \& Humanities Librarian, both at the University of Colorado Boulder; email: lindsay.m.roberts@colorado.edu, megan.welsh@colorado.edu. Brittany Dudek is Library Coordinator at Colorado Community Colleges Online; email: brittany.dudek@cccs.edu. The authors wish to thank the many Colorado librarians who completed the CALTS survey and who are continuing conversations about meeting transfer student needs. Also, many thanks to our col-leagues and reviewers who provided thoughtful feedback to improve the article. (02019 Linds West Roberts, Megan E. Welsh, and Brittany Dudek, Attribution-NonCommercial (http:// creativecommons.org/licenses/by-nc/4.0/)CCBY-NC.
} 
the 2004/2009 Beginning Postsecondary Students Longitudinal Study transferred at least once within six years of starting college, with most students moving from two-year to four-year institutions. ${ }^{3}$ Predictions from NCES indicate that transfer student populations will continue to increase in coming years. ${ }^{4}$ Given these increases, academic libraries on both two-year and four-year campuses have a responsibility to discover how they can support transfer students and contribute to their academic and social engagement. This responsibility aligns with librarianship's shared professional values of access to education and information, especially in light of educational equity issues for community college students, transfer students, and students from diverse backgrounds. ${ }^{5}$

The current paper focuses on instruction and outreach services to transfer students that may contribute to students' academic and social engagement. The authors include the results of the Colorado Academic Library Transfer Survey (CALTS). The survey evaluated three main areas: instruction and outreach services to transfer students; barriers to providing these services; and library professionals' perceptions of transfer student needs. This paper informs scholarship, practice, and policy by:

1. contributing foundational research for the state of Colorado, which has not had a large-scale transfer study in academic libraries before;

2. creating new survey questions regarding academic library outreach, an important category of library service to capture when meeting transfer student needs;

3. adding definitions to information literacy activities to increase specificity of responses;

4. updating the language around instructional activities with current focus on information literacy instead of bibliographic instruction;

5. collecting and analyzing qualitative data from survey respondents that helps shed light on perceptions and barriers of library professionals' practices;

6. contacting more than one person at large libraries to help understand nuances of different library professionals' attitudes and perspectives.

\section{Literature Review}

It can be difficult for educators and library employees to distinguish transfer students from traditional, first-time college students and for academic libraries to construct services and programs that meet the needs of transfer students. The role of the academic library in the lives of college students should not be underestimated. Research suggests a positive relationship between academic libraries and student success. ${ }^{6}$

The largest barrier to engaging transfer students may be related to the difficulty of definitions and availability of data for this population. Collecting data about transfer students is challenging due to disparate definitions between institutions and lack of data that would allow for granular evaluation of the broader transfer student population. Townsend recommends developing better statewide data sets, which would track students' movement across two- and four-year, public and private institutions. ${ }^{7}$ Finding national-level data estimating information about transfer students is particularly difficult. For instance, it is challenging to determine how many different institutions students have attended and to track movement between four-year to two-year institutions, which Peter and Cataldi found to be common among a quarter of the total transfer student population in their study. ${ }^{8}$ Collecting transfer rates depends on the definition of "transfer student" that is used in the study, how the rate is calculated, and over what time period transfer student data is collected. ${ }^{9}$ Many NCES measures, such as graduation 
rates, focus on first-time college students, which may be an indicator of past stigma against transfer students as "dropouts," from a time when data was aggregated for all students who left an institution instead of documenting students who went on to transfer and complete a degree elsewhere. ${ }^{10}$ In fact, the American Association of Community Colleges advocates for more nuanced factors than graduation rates (such as transfer rates and part-time student rates) to be included when comparing institutions. ${ }^{11}$ NCES began collecting and reporting additional information for transfer-in students, including part-time students, with the 2017-2018 academic year. NCES will also collect information on full-year cohorts instead of fall census date cohorts (more accurate for two-year institutions), and completion statistics longer than six years to better track student completion pathways. ${ }^{12}$

\section{Transfer Student Needs and Challenges}

Transfer students face challenges that are well documented in the literature. Much of the early literature on transfer student retention and persistence focused on past predictive factors (race, socioeconomic status, geography) and placed greater emphasis on individual characteristics than on exploring institutional obstacles that impact student retention. ${ }^{13}$ These early works frequently had a deficit perspective with a tendency to view individuals who did not "fit" with the college experience as outliers, rather than questioning whether college systems were constructed to include increasingly diverse student bodies. ${ }^{14}$ The complexity of defining the transfer student population may also be a challenge to identifying best practices for working with transfer students, since no single profile can describe all transfer students' needs. Yet, academic and social engagement are strong predictive factors in transfer students' retention and persistence at the receiving campus. ${ }^{15}$ Recent research highlights institutional areas where changes to programming or administrative processes can increase students' academic and social engagement.

Various studies have reported that transfer students may be ill-prepared academically to transfer from community colleges. ${ }^{16}$ Transfer shock, a decrease in GPA upon completion of the first semester of classes after enrolling at a new institution, is a well-documented phenomenon, though not fully understood..$^{17}$ Cutright points to a need for more research in understanding why transfer shock occurs. Cutright poses two possible scenarios, questioning whether transfer shock is inherent to student ability or if it is attributed to the quality of transitional support provided by the institution. ${ }^{18}$ Current research advocates moving from a simplistic understanding of transfer shock that focuses on the dip in grade point average to a more nuanced understanding of the environment and processes that impact transfer students' adjustment. ${ }^{19}$ There is also evidence of a racial transfer gap for historically underrepresented minority students, which reinforces the need for additional support for transfer students from underrepresented backgrounds. ${ }^{20}$ Additionally, financial aid affects transfer student success and interacts with demographic factors. In a study of their institution, McGuire and Belcheir estimated (based on financial aid records) that 60 percent of transfer students were first-generation college students from low-income backgrounds. ${ }^{21}$ To be clear, a community college background should not necessarily be seen as a risk factor in itself. After reviewing the records of nearly 70,000 students, Auluck and West found few differences in persistence and performance between community college and four-year institution transfers, and students entering as freshmen. ${ }^{22}$ Hagedorn, Cypers, and Lester concluded, "endeavors to assist students to be more engaged in college life and to enjoy their experiences may be positive" but "hollow if not accompanied by intensive academic support and consistent advising services." ${ }^{23}$ 


\section{Academic Libraries and Transfer Students}

Information gathered through Association of College and Research Library's Assessment in Action project suggests correlations between academic libraries and student success and retention. ${ }^{24}$ One of the key findings from the program states, "Academic library partnerships with other campus units, such as the writing center, academic enrichment, and speech lab, yield positive benefits for students (e.g., higher grades, academic confidence, and retention)." ${ }^{25}$ Oliveira found positive correlations between student retention and academic success in three areas: library instruction, library spaces, and use of materials. ${ }^{26}$ Staines found little literature on community college transfer students and their information literacy skills, while Philips and Atwood found little literature discussing the role academic libraries could play in supporting transfer students in general. ${ }^{27}$ Philips and Atwood posit that academic libraries do not offer services, especially library instruction sessions, specifically for transfer students because they are not recognized as having distinct needs..$^{28}$ Academic libraries can do much to understand and accommodate the individual needs of the increasing transfer student population.

The available literature on transfer student needs and academic libraries focuses on library instruction, which plays an important role in developing information literacy and critical thinking skills. Research confirms that teaching transferable skills in library instruction sessions at community colleges is important, yet Cox and Johnson and Staines have found that transfer students do not necessarily receive library instruction at their previous institutions. ${ }^{29}$ Even when transfer students do receive library instruction at former institutions, they may have trouble applying the skills in their new institution, especially for upper-level research assignments. Many academic libraries do not offer specific library instruction for transfer students once they arrive at a new institution. ${ }^{30}$ If transfer students have already taken a lower division writing class at a previous institution (which is often a first exposure to library instruction), they may miss an introduction to the library altogether. ${ }^{31}$ Several scholars have found that first-year students may experience confusion, fear, and feelings of inadequacy or being overwhelmed by their academic library. ${ }^{32}$ Considering the diverse experiences of transfer students, they may especially feel overwhelmed by the complex nature of a new (perhaps larger) academic library and the new institution as a whole. ${ }^{33}$ In fact, community college librarians report former students who have since enrolled at four-year institutions returning to the comfort and familiarity of their community college library instead of using the academic library at their new institution. ${ }^{34}$ Library instruction may also be one way of lessening library anxiety for students. ${ }^{35}$ Research on library anxiety provides guidance for proactive instruction and outreach to transfer students as they transition to a new institution. ${ }^{36}$

Research indicates a need for increased dialogue among institutions and provides a rationale for a more systematic approach to transfer student library instruction. For example, Tag conducted a survey of incoming transfer students at three transition fairs to gather information about students' research abilities and discover what students were most interested in learning about their new academic library. ${ }^{37}$ The results led to several productive changes and recommendations, such as connecting students with subject specialists early on and representing transfer student interests on campus committees. ${ }^{38}$ Philips and Atwood surveyed 72 academic libraries in Ohio to gain an understanding of instructional efforts specifically targeting transfer students across the state. Despite the overwhelming majority of respondents who "indicated that information literacy was integral to their library's mission and perceived it to be an effective way to teach students how to use library resources and services," only 13 percent of survey 
respondents reported a "need for transfer-specific instruction." ${ }^{39}$ Philips and Atwood concluded that concern for the transfer student population was minimal compared to the concern for traditional first-year students. ${ }^{40}$ They discovered that, although "respondents agreed that both two-year and four-year institutions share responsibility to teach information literacy skills that contribute to transfer students' academic success, many stated that they have not done so." ${ }^{41}$

There are opportunities for two-year and four-year schools to better communicate and collaborate around the needs of transfer students. McCallister, Gregor, and Joyner found little communication on information literacy teaching between two and four-year institutions. ${ }^{42}$ Staines advocates cooperative arrangements between community colleges and local academic libraries, including the opportunity for transfer students to take field trips to prospective institutions' libraries. ${ }^{43}$ Staines also found that library professionals make assumptions about student needs and the content covered by other institutions' instruction programs instead of communicating between institutions about student needs and instruction programs. This results in a gap between assumed and actual skills, which ultimately disadvantages the student. ${ }^{44}$

Some academic libraries have explored interventions to meet transfer students' needs. Philips and Atwood created a full-day conversation with librarians from across the OhioLINK consortium to explore a library instruction program specifically for transfer students ${ }^{45}$ These researchers recognized that OhioLINK was positioned to standardize information literacy instruction programs for transfer students and could provide a foundation for students to effectively transfer information literacy skills across institutions. ${ }^{46}$ Although core electronic resources were available throughout the state, library instruction sessions promoting these resources could vary greatly depending on the institution and the library instructor.

In terms of specific actions, the literature suggests that libraries can provide orientation or instruction sessions aimed at transfer students, credit classes for transfer students taught by librarians or in partnership with librarians, and workshops to educate library personnel on transfer student needs. ${ }^{47}$ Administrative support to engage in partnerships with other units on campus, such as student affairs or advising offices, has also been shown to be helpful. ${ }^{48}$ Some institutions discuss the use of techniques they employ with traditional first-year students that can be adapted for transfer students. For example, peer interactions and word-of-mouth were found to be more effective at reaching students than other marketing channels at Oakland University. ${ }^{49}$ Also at Oakland, transfer students who have adjusted to their new institution serve as peer library advocates, similar to orientation group leaders serving in this role for incoming freshmen..$^{50}$ Though additional case studies and support are needed, collaboration is thought to lead to partnerships, enhanced communication, and increased knowledge of resources at different institutions, which in turn could help students transfer skills acquired at one institution to their next. In summary, research indicates that libraries can help students transitioning to a new institution. However, it is not well understood how widely the research recommendations have been adopted into practice or what challenges may be preventing their adoption. This article provides a picture of transfer student instruction and outreach activities across the state of Colorado.

\section{Methods}

This study addressed the following research questions:

1. What instruction and outreach services do academic libraries provide to transfer students in two- and four-year institutions in Colorado? 
2. What is the perceived need to engage with transfer students as a distinct population in two- and four-year institutions in Colorado?

\section{Survey}

The authors developed a survey based on Phillips and Atwood's survey to Ohio libraries, which was derived from Staines' survey in New York state. ${ }^{51}$ This article builds on prior survey research from New York and Ohio through generalization, where similar procedures are repeated in a new geographic location some years after the earlier studies. ${ }^{52}$ Such replication is valuable in showing whether trends hold across geographic areas and after the passage of time. The New York and Ohio surveys are the only published examples of surveys regarding academic libraries and transfer students at a statewide level. These publications are credible and significant contributions to the existing literature. Thus, the authors chose to adapt the prior surveys for the Colorado context.

The majority of Colorado community colleges are part of the Colorado Community College System, though they function individually and there are a few public two-year institutions that are outside this system. Some community colleges now offer advanced degrees in addition to associates degrees and certificate programs. Many Colorado community colleges have a solo librarian or very small academic library staff. Budgets and facilities vary based on their institution's priorities. Colorado's public community college system is completely separate from public colleges and universities. There are two distinct public four-year university systems, University of Colorado and Colorado State University, as well as a number of standalone public institutions, such as Colorado School of Mines and Western State University. Private institutions in the state include vocational, seminary, two-year, and four-year schools. These institutions vary widely in size, budget, and academic library facilities.

In light of Colorado's academic library context, question language was adapted to represent changes in technology and terms used in the Colorado library community. For example, Colorado does not have such a defined resource-sharing network as Ohio. Colorado academic libraries have some commonly held databases through an optional consortium package, but the state does not have as many formal structures to support collaboration across academic libraries as other states. Specific instruction and outreach definitions were added as well, derived from definitions created by University of Colorado Boulder's Instruction Working Group..$^{53}$ In contrast to the five-point scales on the Staines survey and the Phillips and Atwood survey, Likert questions on this version used a four-point scale. This was an intentional choice intended to reduce "mid-point" responses and allow the authors to more clearly observe distinctions in library professionals' perceptions. The authors created additional questions for this survey regarding library outreach activities for transfer students. A panel of experts reviewed the survey and made recommendations. The final survey is in appendix A.

The online survey was sent via email to 107 library professionals at 17 two-year, vocational, and seminary institutions and 26 four-year institutions that had accepted or prepared transfer students according to the Colorado Department of Higher Education Transfer (At Entry) Summary FY 2014-2015. ${ }^{54}$ Institutions included both public and private colleges and one federal academic library in Colorado. Where identifiable, the authors prioritized instruction librarians in email invitations, followed by library directors, or library employees who presumably regularly interact with students. If no one who met this description was available, the authors contacted any library representative or person responsible for the library at their institution. At institutions 
with many instruction librarians, more than one library employee was contacted. This was intended to better capture the range of perceptions and attitudes that exist within institutions.

\section{Analysis}

Because question wording from the Staines survey and the Phillips and Atwood survey was modified and new questions were added, Cronbach's alpha was calculated for each of the four subscales on the survey, with results in table 1 showing strong internal consistency for each subscale. For the quantitative responses, frequency charts and graphs were used for descriptive statistics. Additional analysis was

\begin{tabular}{|l|c|c|}
\hline \multicolumn{3}{|c|}{ TABLE 1 } \\
\hline \multicolumn{1}{|c|}{ Internal Consistency of Survey Subscales } \\
\hline \multicolumn{1}{|c|}{ Subscale } & $\begin{array}{c}\text { Number of } \\
\text { Items }\end{array}$ & $\mathbf{a}$ \\
\hline Information Literacy & 4 & 0.79 \\
\hline Transfer Student Information Literacy* & 4 & 0.71 \\
\hline Transferable Skills and Resources & 6 & 0.84 \\
\hline Shared Responsibility & 3 & 0.81 \\
\hline *When calculated with "Integrating library instruction for transfer \\
students into my information literacy sessions is difficult," alpha is \\
$\begin{array}{l}0.61 \text { and 0.2 average interim covariance. Due to concerns about } \\
\text { question wording, this question was removed from data analysis. }\end{array}$ \\
\hline
\end{tabular}
conducted using STATA 14 soft-

ware, including cross-tabulations and a chi square test for independence for all Likert questions. For the survey's two qualitative questions, the authors began by developing a core list of codes after reviewing responses. The authors then conducted a round of coding individually and applied the codes that seemed to be the best fit, making notes for additional codes and new or challenging interpretations of codes. The researchers discussed the codes as a group and developed a revised list of codes. A final round of individual coding ensued, followed by a last set of in-depth discussions until consensus on final codes was reached.

\section{Findings}

\section{Quantitative Results}

The Colorado Transfer Summary Report 2014-2015 lists 57 Colorado colleges or universities that accepted or prepared transfer students in $2015 .{ }^{55}$ The authors contacted 43 of these institutions excluding institutions that had closed, were closing, or had not transferred any students to a public four-year institution in 2015. Sixty library professionals started the survey out of 107 contacted, resulting in 55 responses with enough completed questions to be included in data analysis (a $51.4 \%$ response rate, representing 29 libraries around the state). Table 2 details the institutions or individuals contacted and response rates.

\begin{tabular}{|c|c|c|c|c|}
\hline \multicolumn{5}{|c|}{$\begin{array}{c}\text { TABLE } 2 \\
\text { Survey Respondents }\end{array}$} \\
\hline & \multicolumn{2}{|c|}{ Institutions } & \multicolumn{2}{|c|}{\begin{tabular}{|l|} 
Individuals \\
\end{tabular}} \\
\hline & Contacted & Responded & Contacted & Responded \\
\hline \multicolumn{5}{|c|}{ Four-Year } \\
\hline Public & 13 & 10 & 52 & 30 \\
\hline Private & 13 & 10 & 30 & 12 \\
\hline \multicolumn{5}{|c|}{ Two-Year/Vocational/Seminary } \\
\hline Public & 14 & 8 & 21 & 12 \\
\hline Private & 3 & 1 & 4 & 1 \\
\hline Total & 43 & 29 & 107 & 55 \\
\hline \multicolumn{5}{|c|}{$\begin{array}{l}\text { Note: Librarians representing the tri-institution, joint-use } \\
\text { Auraria Library were counted as representing one institution. } \\
\text { Colorado Department of Higher Education listings for private/ } \\
\text { public institutions were used where discrepancies were found } \\
\text { with participants' self-reported institution types. }\end{array}$} \\
\hline
\end{tabular}




\section{Institutional Questions}

Some of the questions on the survey address institutional services and practices for transfer students: questions 4-6, 12-16, and 19 (see appendix A). Regarding transfer student-specific orientation (question 12), out of 20 four-year institutions, four libraries indicate that they have a designated transfer student orientation and none of the two-year institutions report transfer student orientations (shown in table 3). Yet, the authors find 9 four-year institutions and 3 two-year institutions show discrepancies among responses from individual librarians about whether their institution offered a transfer student-specific orientation. The authors reviewed responses and institutional websites to try to consistently code conflicting responses. Individual librarians at three institutions disagree about whether their institution had a transfer stu-

\begin{tabular}{|l|c|c|c|c|c|}
\hline \multicolumn{7}{|c|}{ TABLE 3 } \\
Responses to “Does your school have a \\
designated transfer orientation?"
\end{tabular}
dent-specific orientation. Reviews of the websites for those three institutions found they do offer a transfer studentspecific orientation. Nine institutions appear to have a general orientation for both transfer students and incoming freshmen, although some of these institutions may offer transfer-specific sessions during an orientation day.

Out of 29 libraries, 55.6 percent of libraries at two-year institutions and 80 percent of those at four-year institutions indicate that they have a presence at their institution's new student orientation, which includes transfer students, but only 12.4 percent have a presence at orientations meant specifically for transfer students. Few institutions, 2 two-year and 4 four-year, report that they collaborate with other departments on campus to participate in transfer student activities. Of 29 libraries, only one four-year institution reports offering transfer students a welcome event specifically sponsored by the library. These responses indicate that, while few libraries are providing transfer student-specific services, transfer students may receive outreach through campus opportunities meant for the general student population.

All 29 institutions indicate that they hold information literacy sessions at their institutions, which may include transfer students in mixed classes. However, when asked about information literacy activities for transfer students, only 2 four-year institutions report offering sessions specifically for transfer students. None of the academic libraries at two-year institutions indicate distinct library instruction for transfer students. When asked if they plan to create information literacy classes or workshops for transfer students in the future (question 19), responses from 11 of 29 institutions reveal discrepancies among colleagues (see table 4). One four-year institution did indicate plans to create information literacy classes for transfer students.

Libraries engage with transfer students via other methods. Table 5 shows responses to questions about types of general information literacy activities offered at each institution compared with information literacy activities for transfer students, spe-

\begin{tabular}{|c|c|c|c|c|c|}
\hline \multicolumn{6}{|c|}{$\begin{array}{c}\text { TABLE 4 } \\
\text { Responses to “Is your library planning to create } \\
\text { separate information literacy classes or workshops } \\
\text { for transfer students?" }\end{array}$} \\
\hline & Yes & No & Unsure & Discrepancy & $\begin{array}{c}\text { Number of } \\
\text { Libraries }\end{array}$ \\
\hline Two-Year & 0 & 6 & 1 & 2 & 9 \\
\hline Four-Year & 1 & 8 & 1 & 9 & $20^{*}$ \\
\hline
\end{tabular}


cifically. For example, 96.6 percent of 29 libraries provide individual appointments to all students, including transfer students. Of the two institutions who report conducting information literacy activities specifically for transfer students, individual appointments and orientations are the teaching methods they both use (see table 5).

\begin{tabular}{|l|c|c|c|c|}
\hline \multicolumn{4}{|c|}{ Information Literacy Activities Overall and for Transfer Students } \\
\hline \multirow{2}{*}{ Activity } & \multicolumn{2}{|c|}{$\begin{array}{c}\text { Information Literacy } \\
\text { General Activities }\end{array}$} & $\begin{array}{c}\text { Transfer-Specific Student } \\
\text { Activities }\end{array}$ \\
\cline { 2 - 5 } & Two-Year & Four-Year & Two-Year & Four-Year \\
\hline Individual Appointments & $9(100 \%)$ & $19(95 \%)$ & $0(0 \%)$ & $2(10 \%)$ \\
\hline Research Guides & $8(89 \%)$ & $18(90 \%)$ & $0(0 \%)$ & $0(0 \%)$ \\
\hline Handouts & $9(100 \%)$ & $13(65 \%)$ & $0(0 \%)$ & $1(5 \%)$ \\
\hline Screencast Videos & $8(89 \%)$ & $15(75 \%)$ & $0(0 \%)$ & $1(5 \%)$ \\
\hline Interactive Online Tutorials & $4(44 \%)$ & $5(25 \%)$ & $0(0 \%)$ & $0(0 \%)$ \\
\hline Virtual Course Integrated Instruction & $2(22 \%)$ & $9(45 \%)$ & $0(0 \%)$ & $1(5 \%)$ \\
\hline Face-to-face Course Instruction & $6(67 \%)$ & $19(95 \%)$ & $0(0 \%)$ & $1(5 \%)$ \\
\hline Embedded Course & $3(33 \%)$ & $16(80 \%)$ & $0(0 \%)$ & $0(0 \%)$ \\
\hline Librarian-led Credit Course & $0(0 \%)$ & $4(20 \%)$ & $0(0 \%)$ & $0(0 \%)$ \\
\hline Orientation & $6(67 \%)$ & $18(90 \%)$ & $0(0 \%)$ & $2(10 \%)$ \\
\hline Library Tours & $7(78 \%)$ & $13(65 \%)$ & $0(0 \%)$ & $1(5 \%)$ \\
\hline Workshop (not tied to a course) & $4(44 \%)$ & $14(70 \%)$ & $0(0 \%)$ & $1(5 \%)$ \\
\hline Special Events Programming & $5(56 \%)$ & $11(55 \%)$ & $0(0 \%)$ & $0(0 \%)$ \\
\hline Assignment Consultations with Faculty & $6(67 \%)$ & $12(60 \%)$ & $0(0 \%)$ & $1(5 \%)$ \\
\hline None of the Above & $0(0 \%)$ & $0(0 \%)$ & $0(0 \%)$ & $0(0 \%)$ \\
\hline Other & $0(0 \%)$ & $1(5 \%)$ & $0(0 \%)$ & $0(0 \%)$ \\
\hline Total Libraries & 9 & 20 & 0 & 2 \\
\hline Note: Counts show number of libraries that responded that they use these techniques. Percentages \\
divided by the total number of two-year or four-year libraries who responded. See appendix for full \\
definitions of each activity. Participants were asked to select all that applied. & \\
\hline & & & & \\
\hline
\end{tabular}

\section{Individual Questions}

Several questions on the survey ask about individual librarians' perceptions and attitudes, which offer insight into behavior and perceived barriers to working with transfer students at different institutions. These are questions $7-11,17,18,20,21-25$, and $26-32$ in appendix A. There is strong agreement between two- and four-year library professionals that information literacy is integral to the library mission and is an effective use of budgetary resources and staff time ( 96.3 percent agree or strongly agree out of 54 responses). Yet, according to the survey responses, notable differences exist between general and transfer-specific library instruction statistics and attitudes, which suggests that transfer students may be missing academic library services.

The authors find disagreement among two- and four-year respondents over whether there is a need for transfer student information literacy instruction, which may be due to different levels of awareness about the size and needs of the transfer student population (see figures 1 and 2). 


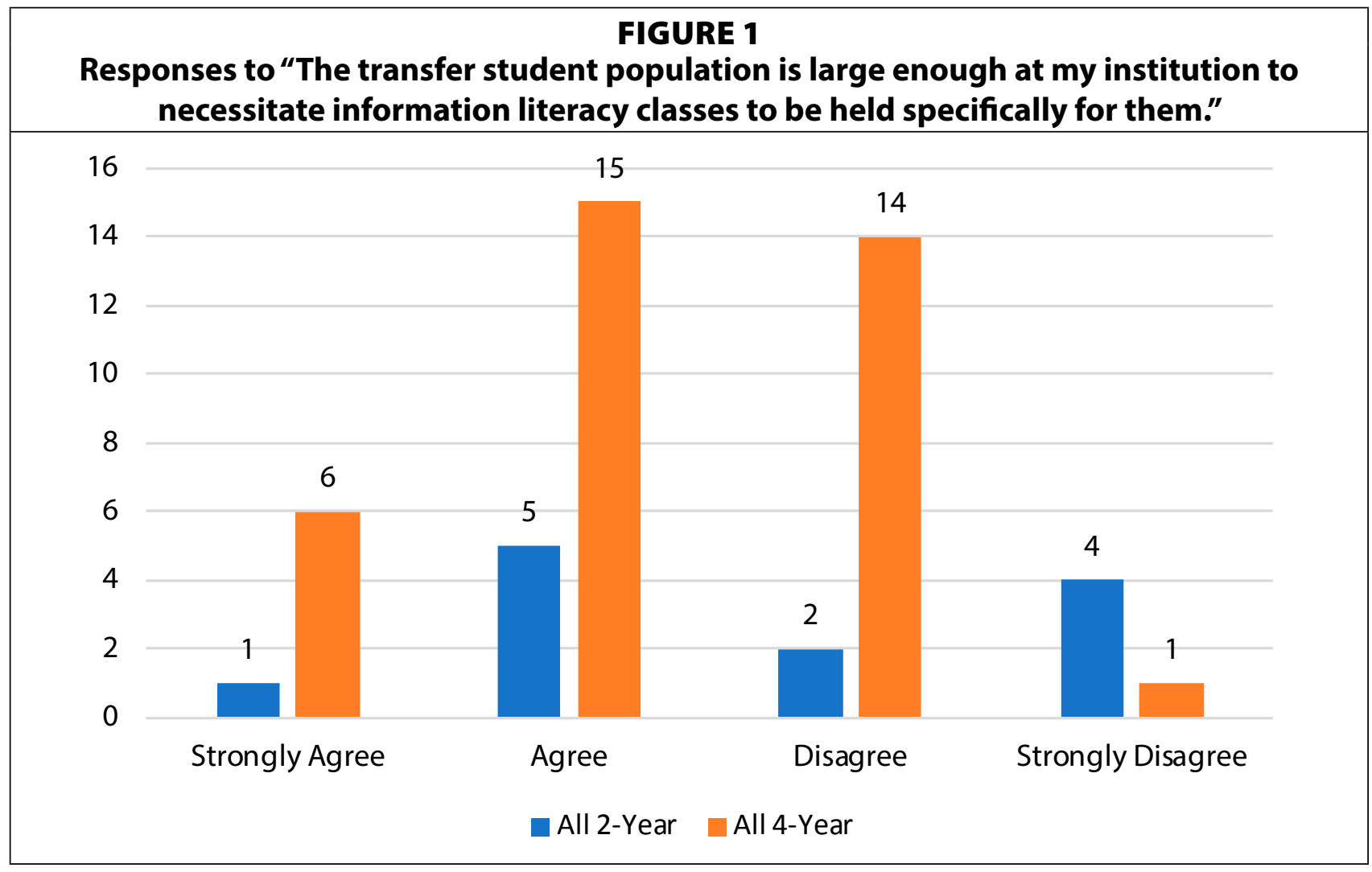

The majority of four-year library professionals, 30 out of $36(83.3 \%)$, agree that there is a need for transfer student-specific instruction. Two-year library professionals are split on this question, with 7 of 13 (53.8\%) in agreement with the statement and $6(46 \%)$ two-year professionals in disagreement.

\section{FIGURE 2}

Responses to "There is a need for transfer student information literacy instruction."

25

22

20

15

10

$$
8
$$

5

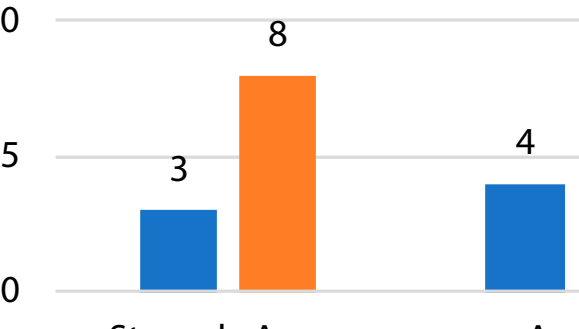

Strongly Agree

Agree

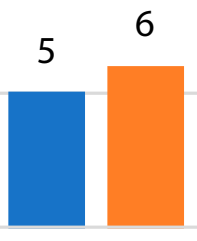

Disagree
1

Strongly Disagree

All 2-Year all 4-Year 
Marked variance occurs between four-year and two-year library professionals when considering the needs of transfer students compared to freshmen at a particular institution. Seventy-five percent (27 out of 36) of four-year library professionals agree that transfer student needs differ from those that started at institutions as freshmen, while 72.7 percent ( 8 out of 11) of two-year library professionals disagree (see figure 3 ).

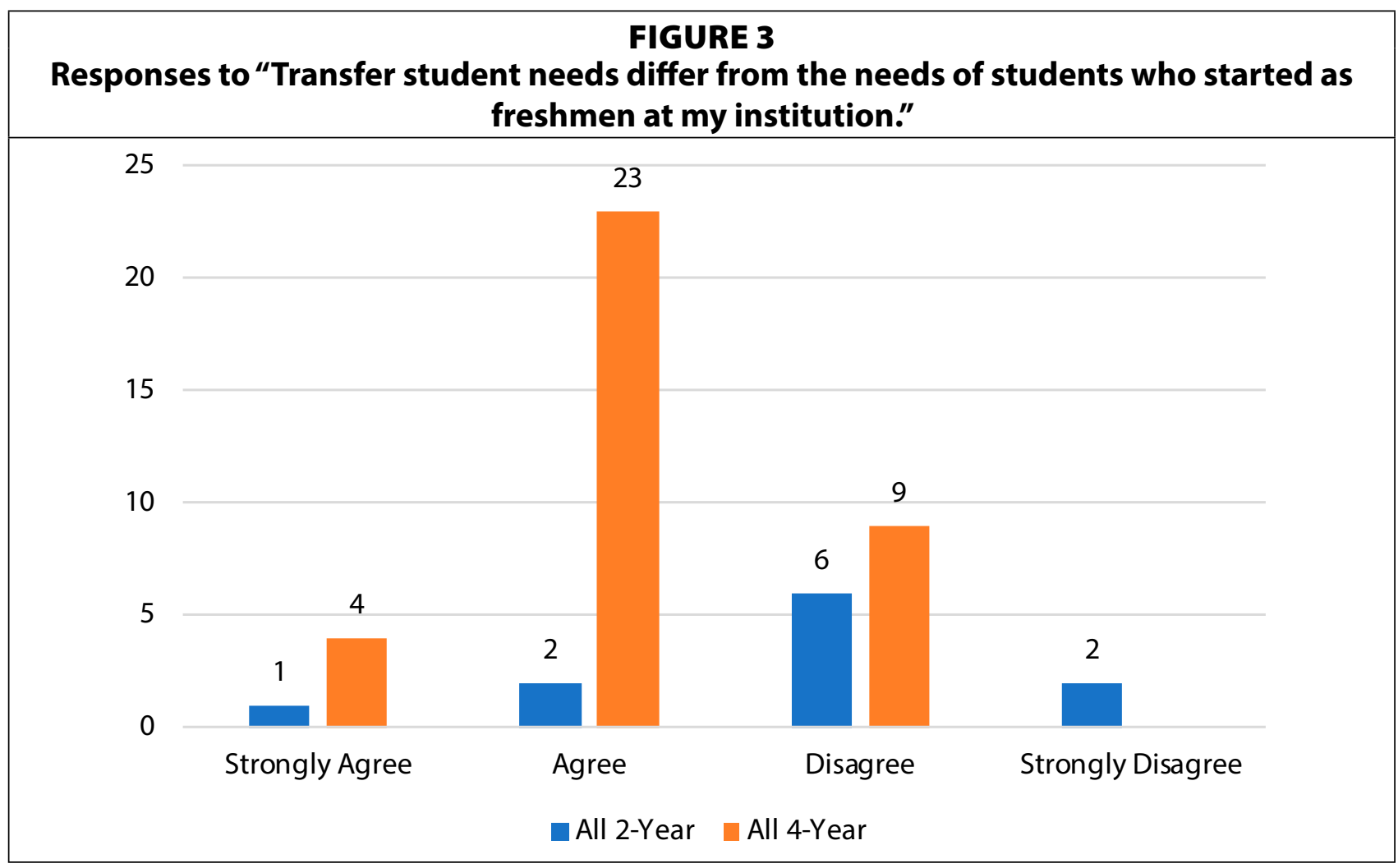

Chi square tests for independence for these questions indicate a significant difference in opinion associated with library professionals at two-year and four-year institution types (see table 6).

\begin{tabular}{|c|c|c|c|c|c|c|}
\hline \multicolumn{7}{|c|}{$\begin{array}{c}\text { TABLE } 6 \\
\text { Variables with Significant Relationships to Institution Type }\end{array}$} \\
\hline \multirow[t]{2}{*}{ Likert Statement } & \multicolumn{2}{|c|}{ Agree } & \multicolumn{2}{|c|}{ Disagree } & \multirow{2}{*}{$\begin{array}{c}X^{2} \\
(\mathbf{d f}=1)\end{array}$} & \multirow[t]{2}{*}{$\mathbf{P}$} \\
\hline & $\begin{array}{l}\text { Two- } \\
\text { year }\end{array}$ & $\begin{array}{c}\text { Four- } \\
\text { year }\end{array}$ & $\begin{array}{l}\text { Two- } \\
\text { year }\end{array}$ & $\begin{array}{c}\text { Four- } \\
\text { year }\end{array}$ & & \\
\hline $\begin{array}{l}\text { There is a need for transfer student information literacy } \\
\text { instruction. }\end{array}$ & 7 & 31 & 6 & 6 & 4.73 & 0.03 \\
\hline $\begin{array}{l}\text { Transfer student needs differ from the needs of students } \\
\text { who started as freshmen at my institution. }\end{array}$ & 3 & 28 & 8 & 9 & 8.69 & 0.003 \\
\hline $\begin{array}{l}\text { Information literacy sessions routinely make students } \\
\text { aware that resources are available at other academic } \\
\text { libraries across the state (such as EBSCO databases). }\end{array}$ & 12 & 31 & 0 & 11 & 3.95 & 0.047 \\
\hline
\end{tabular}


In terms of barriers to providing transfer student-specific library activities, table 7 indicates the primary reasons reported, with these responses as the top three choices: "hadn't considered offering activities for transfer students," "other," and "limited staffing." Yet, when asked whether they agree with the statement, "My library is adequately staffed to teach information literacy skills to transfer students," 49 respondents, 75 percent of four-year and 46.2 percent of two-year library professionals, perceive that they are adequately staffed to teach information literacy skills to transfer students. Given the variation in size and budgets at academic institutions across Colorado, it is not surprising that library professionals perceive a range of barriers that may prevent their libraries from offering any transfer-specific library activities.

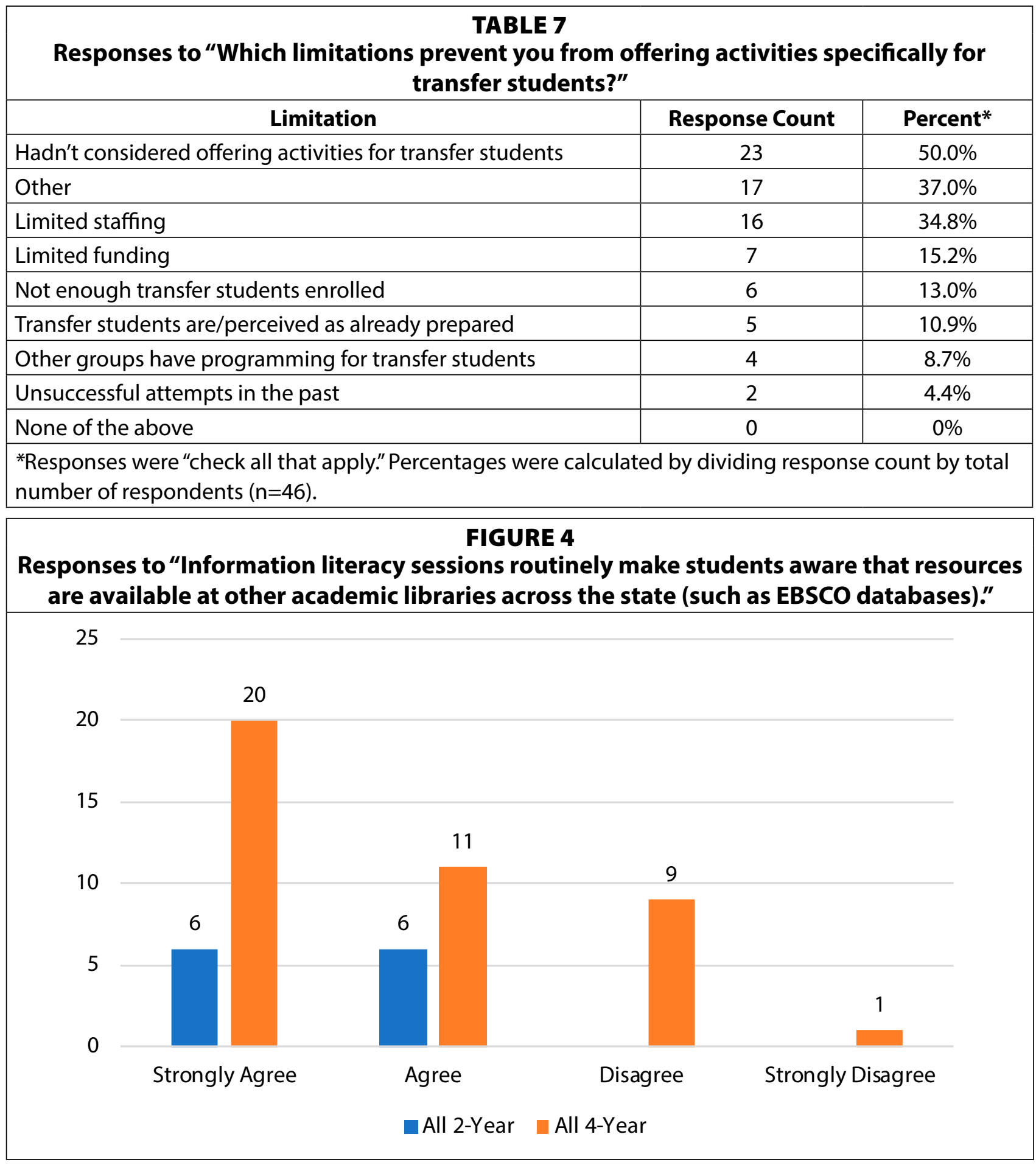


Library professionals largely agree about the importance of transferable skills and the value of shared library resources. All 49 respondents agree or strongly agree that students should be able to transfer their library research skills from one academic library to another, while the majority of respondents $(77.55 \%)$ at two-year and four-year institutions agree that students at their institutions routinely use resources found at academic libraries throughout the state (see figure 4).

Library professionals disagree, however, about whether or not academic libraries should focus on teaching the wide array of library services and resources found across Colorado or primarily those at their own institutions (see figure 5). Of the 49 responses, 23 agree that their own library's resources should be the focus of instruction, and 26 disagree, a nearly even split (see figure 5). The results of this question vary significantly across library professionals at different institution types from the chi square test for independence (see table 6). In practice, however, 53 survey respondents $(81.14 \%)$ strongly agree or agree that their information literacy instruction routinely makes students aware of the resources available at other academic libraries across the state. This widespread perception may be due to the Colorado Library Consortium (CLiC) shared database packages, to which, in Fiscal Year 2018, 18 two-year and 26 four-year libraries, as well as most public libraries, subscribe (numbers provided by CLiC via email).

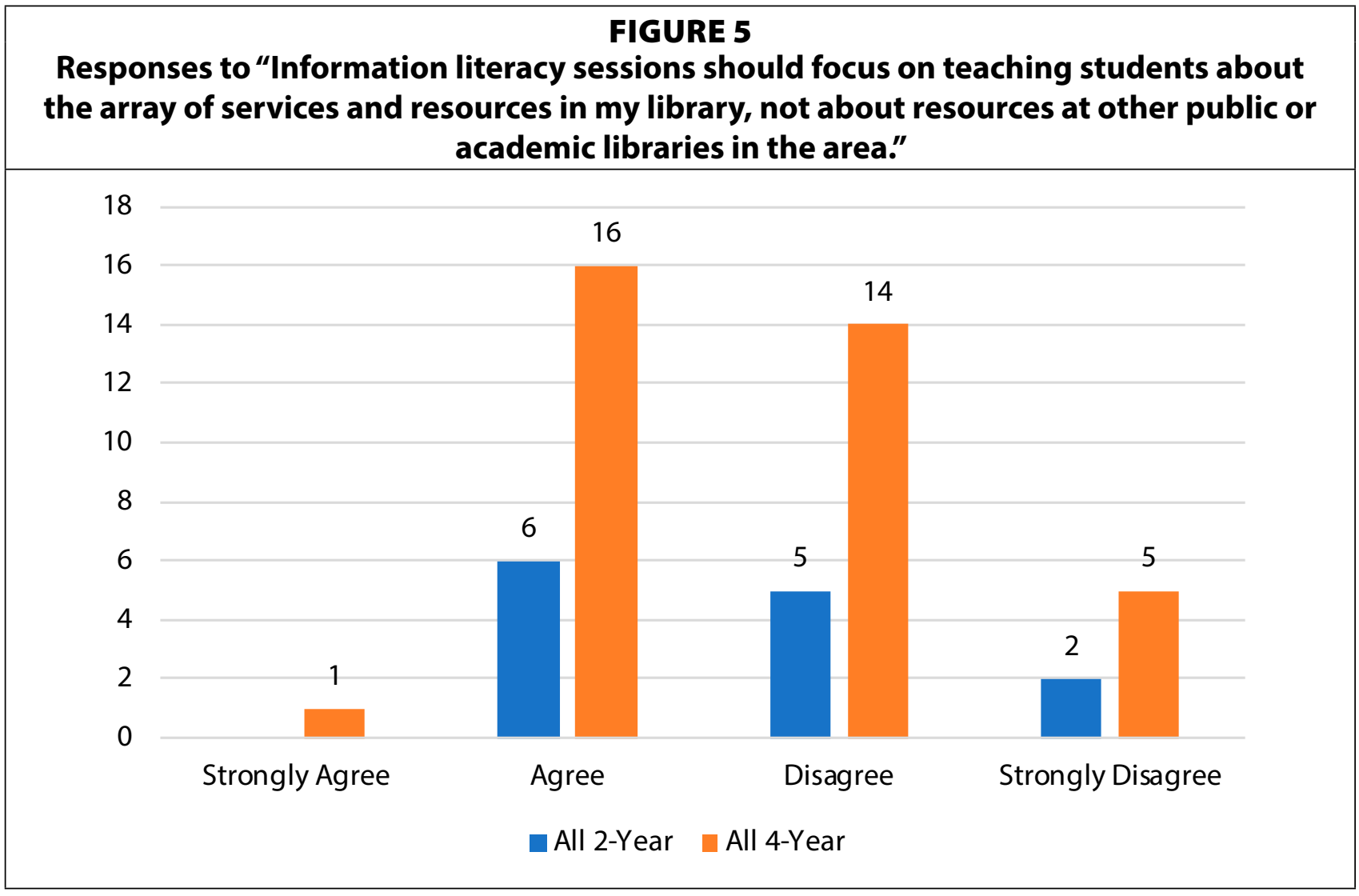

There are positive signs that library professionals view future collaboration among Colorado institutions as a way to address gaps in services to transfer students.

Survey respondents generally agree that cooperation among academic libraries is beneficial to transfer students (45 of 47 participants agree or strongly agree) (see figure 6). 


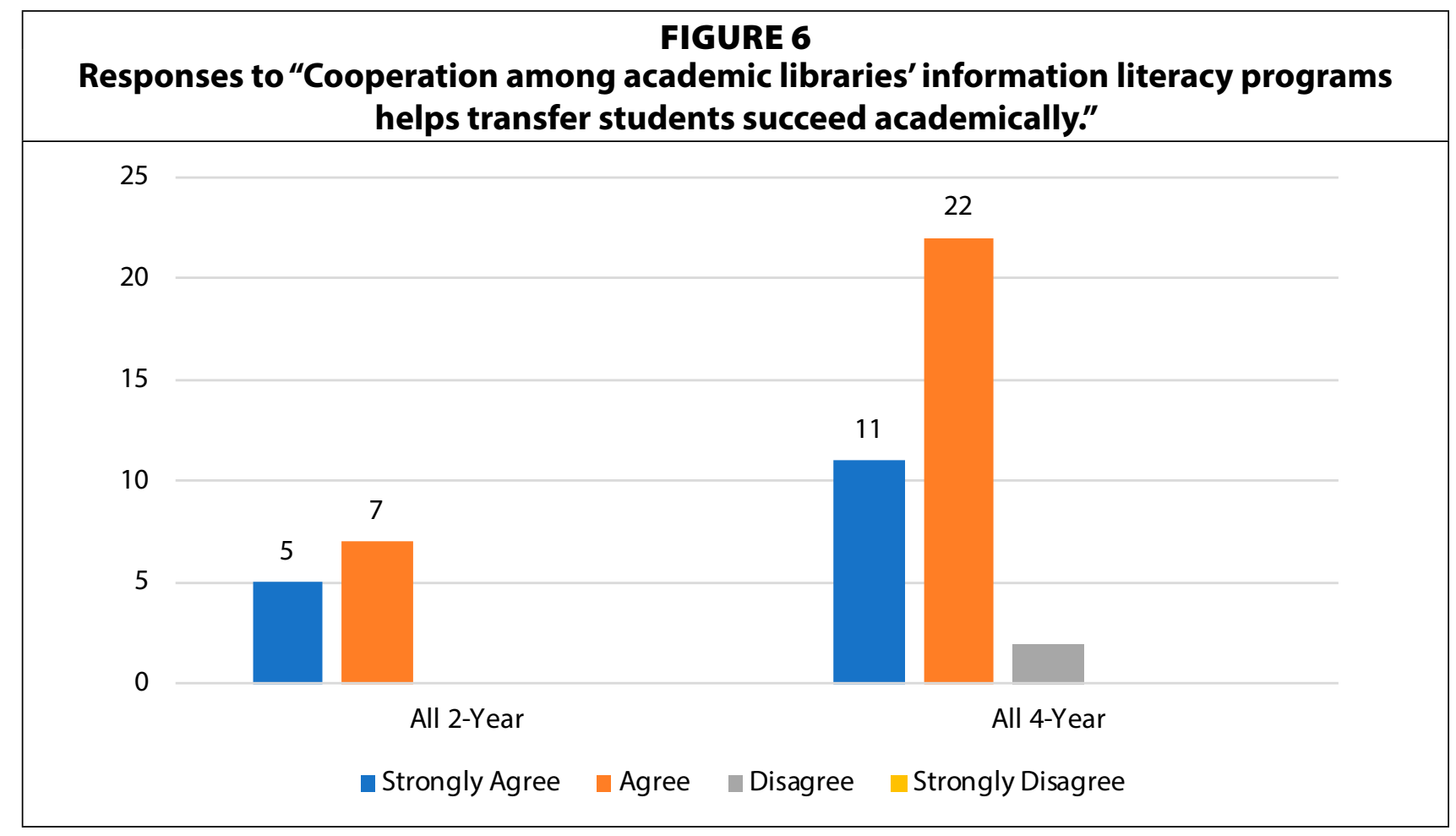

When asked whether community colleges had the sole responsibility for teaching library research skills to transfer students, 90 percent of all responses disagree with the statements, indicating that they believe the responsibility should be shared across institution types (see figures 7 and 8).

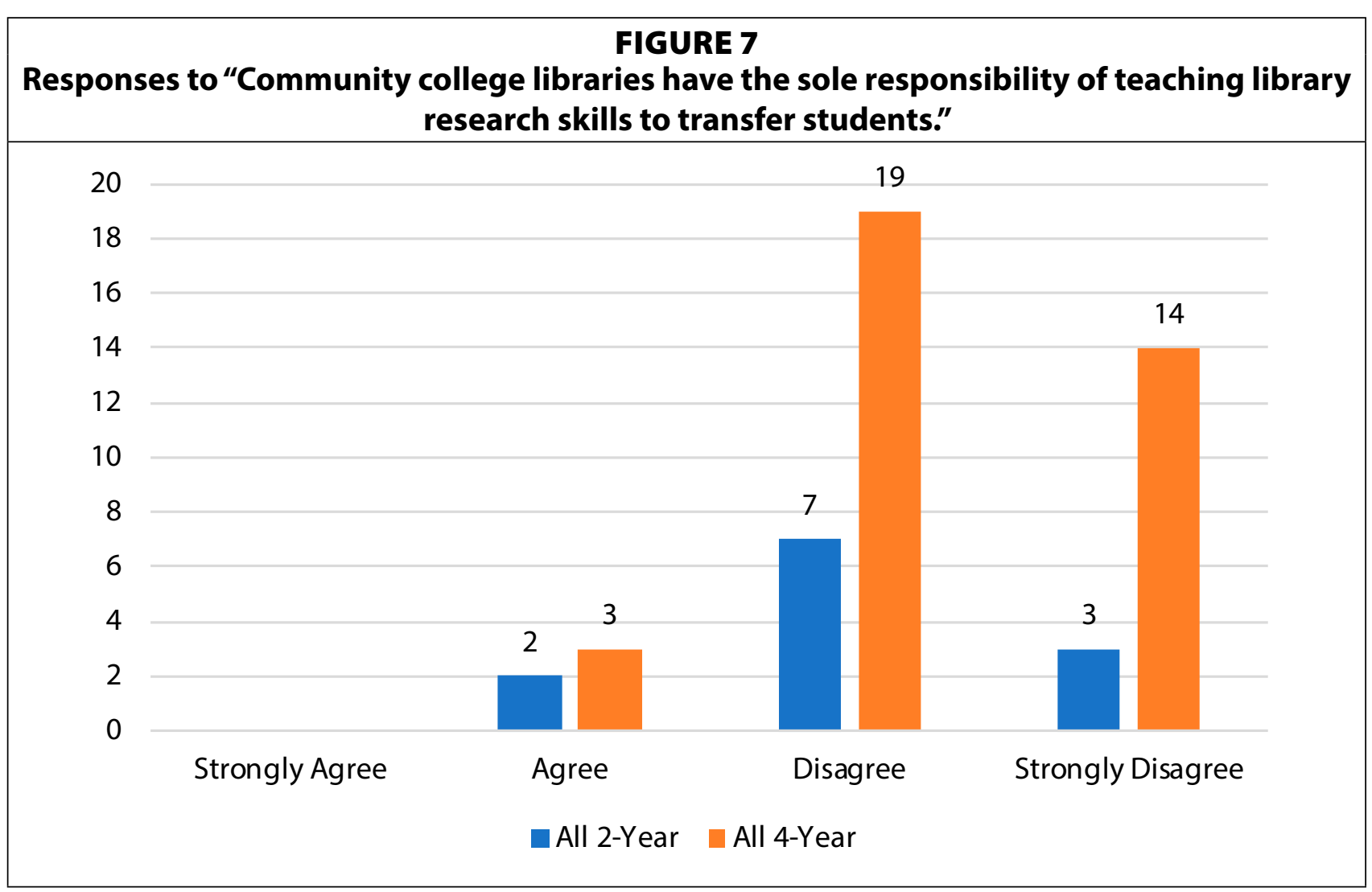




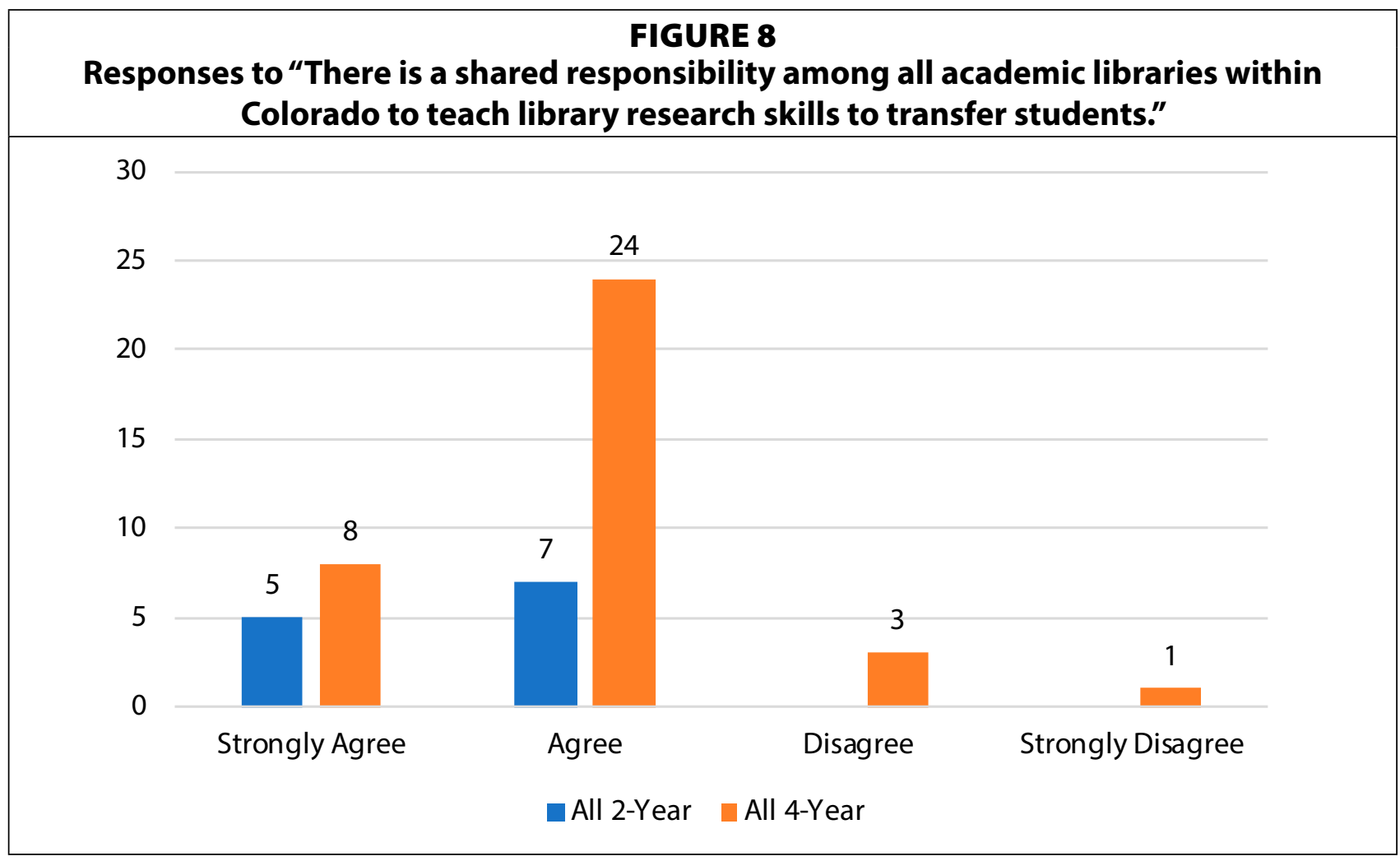

\section{Qualitative Results}

Two survey questions contain many qualitative comments from respondents. The first asks "Which of these prevent you from offering activities specifically for transfer students?" and allows respondents to check as many as nine options identifying barriers, including a "None of the above" and an open-ended "other" option. There are seventeen responses for "other" (22.7\% of two-year respondents and $20.7 \%$ of four-year respondents) including qualitative comments in response to this question. A concluding comments question asks, "Is there anything you think we should know about transfer students and your library?" Again, there are seventeen responses to this question: seven from two-year colleges and ten from four-year settings.

\begin{tabular}{|l|c|c|c|}
\hline \multicolumn{1}{|c|}{ Trequency of Coded Themes in Open-Ended Questions } \\
\hline \multicolumn{1}{|c|}{ Code } & $\begin{array}{c}\text { Barrier } \\
\text { Comments }\end{array}$ & $\begin{array}{c}\text { Concluding } \\
\text { Comments }\end{array}$ & $\begin{array}{c}\text { Total } \\
\text { Frequency }\end{array}$ \\
\hline $\begin{array}{l}\text { Perception that transfer students are being reached through } \\
\text { subject specialist or in upper division classes }\end{array}$ & 4 & 9 & 13 \\
\hline $\begin{array}{l}\text { Transfer students are not distinguished from other students in } \\
\text { library instruction sessions }\end{array}$ & 5 & 4 & 9 \\
\hline $\begin{array}{l}\text { Unsure how to reach transfer student population for targeted } \\
\text { programs or services }\end{array}$ & 5 & 2 & 7 \\
\hline Recognize there is a need for transfer activities & 2 & 5 & 7 \\
\hline Transferable skills or resources & 0 & 7 & 7 \\
\hline Hard to identify transfer students as a distinct population & 3 & 3 & 6 \\
\hline $\begin{array}{l}\text { Transfer students captured with all incoming or freshmen } \\
\text { students in first-year orientations, classes, or activities }\end{array}$ & 4 & 1 & 5 \\
\hline
\end{tabular}


From participant responses to the "other" and "barrier" questions, the following qualitative research question emerged: "What are the perceived barriers to providing academic library services to transfer students?" The authors assigned 31 codes to responses associated with the "other" choice in the "barrier" question and 57 assigned to responses in the "concluding comments," summarized in table 8. The major themes represented in the codes are challenges to engaging transfer students, population awareness, current outreach and services, and librarian attitudes.

For both questions, respondents report institutional barriers to engaging with transfer students including being unsure how to reach this population $(n=7)$ and the transfer population itself being hard to identify as a distinct population $(n=6)$. More specifically, respondents express the fact that transfer students are not readily identified in the context of library instruction sessions $(n=9)$. One respondent comments that they are " $[u]$ nsure how to specifically target transfer students since our sessions are during class time and this includes both transfer and non-transfer students." Another respondent states that they "...do not ask students if they will be transferring or not and the instruction is based on the skills needed, not whether or not they are transferring... The training is the same for all and considered life skills." Other emerging themes that align with the options provided in the barrier question are limited resources, with insufficient staffing experienced by four respondents. Two other statements indicate that participants have other priorities more important than offering services to transfer students as a specific population. For example, one respondent reports a focus on concurrently enrolled students. Further investigation should be conducted to better understand why other priorities may be more important for these participants, especially if prioritizing other efforts or populations is a result of limited staffing or funding. Another barrier that emerges in two responses is the perception that previous standalone workshops and activities for transfer students did not meet expectations in the past. The perception that outreach or instruction efforts are not successful may be related to a need to prioritize and direct resources (staffing and funding) to other activities that have proven successful over time.

Comments show variance in awareness of transfer student populations. Some respondents recognize that they have many transfer students (three respondents from four-year settings and one from a two-year setting), while two respondents (both from a four-year setting) perceive very few transfer students at their institutions, and two respondents (both from four-year settings) admit that they do not know the number of transfer students at their institutions. As the quantitative findings above suggest, there is an opportunity to raise awareness about the needs and numbers of transfer students served by Colorado academic libraries.

Open-ended comments on outreach and services indicate areas for growth in engaging transfer students. The code most frequently assigned suggests many respondents perceive that transfer students are effectively being reached through subject specialists $(n=13)$ or that they are reached with all incoming or freshman students in first-year orientation, classes, or other activities $(n=5)$. There may be a disconnect between respondent perceptions and how transfer students are actually engaged by library personnel. In their written comments, respondents also report reaching transfer students through one-on-one consultations $(\mathrm{n}=$ 3 ), a strategy commonly employed with students (54 of 55 respondents report conducting individual appointments with students). In summary, there is an assumption that subject specialists, information literacy classes, and individual appointments reach transfer students through the general student population without the need for targeted outreach. 
Open-ended comments also capture librarian attitudes and perceptions. Seven respondents reference the importance of transferable skills across higher education and foundational skills from high school. One of these respondents from a four-year library emphasizes the similarities between resources at academic libraries. A two-year participant comments, "It's our belief that there should also be info lit instruction occurring at the high school level. It's shocking how little (or no) info lit skills are known by recent high school grads," implying that students lack these skills in their new higher education environment. Additionally, two respondents report fostering positive relationships between libraries and transfer students, seven respondents indicate that there is a recognized need for transfer student activities, and one respondent specifically connects this need to the fact that students can transfer skills between two- and four-year institutions. Relatedly, two respondents observe a gap in services provided to transfer students. In both instances, respondents lament that transfer students miss early library interventions associated with their traditional peers who may experience information literacy sessions early in their college careers. These responses, which reinforce library-sponsored activities for transfer students, are contradicted by the respondents who perceive that transfer students should be treated the same as other students $(n=3)$ and those who report that there is no need to target services to transfer students $(n=3)$.

\section{Limitations}

The review of the literature indicated the complexity of defining transfer students. This complexity was reflected in the findings from the CALTS survey. In an effort to capture a variety of responses, the authors did not define the transfer student population at the beginning of the survey. This may have resulted in a lack of participation from two-year institutions when answering questions about services and instruction provided to transfer students. For example, all 9 two-year academic libraries indicated that they did not teach any information literacy classes specifically to transfer students. No community colleges indicated that they were planning to host information literacy sessions for transfer students in the future (six answered "no" and one answered "unsure," and within two libraries, individual librarians disagreed). If a definition had been provided, perhaps more two-year respondents would have acknowledged a role in engaging with both transfer students entering their institution and those preparing to transfer elsewhere. Additionally, the authors' analysis of survey responses indicated confusion between two potential types of orientations for transfer students at community colleges: students transferring into a community college and preparing students to transfer to a four-year institution.

The authors discarded one item from analysis, "Integrating library instruction for transfer students into my information literacy sessions is difficult," due to concerns that the negative wording confused respondents and contradicted other questions on the survey.

Although the authors distributed the survey across the state of Colorado, not all institutions identified on the CDHE transfer report who received the survey responded.$^{56}$ Additionally, two vocational institutions were missed during the update from the 2014 to 2015 Colorado Transfer (At Entry) Summary report and were not contacted. ${ }^{57}$ More four-year librarians $(\mathrm{n}=$ 42) responded to the survey than did librarians from two-year institutions $(n=13)$. Although fewer librarians from community colleges responded, two-year institutions in Colorado have smaller staff sizes. The responses gathered capture perspectives from 8 of 13 institutions of community college libraries in Colorado. 
Branching questions were an integral part of this survey design; thus, participants were not necessarily shown all survey questions. Additionally, some questions allowed for multiple answers, and respondents were not required to answer every question on the survey. As a result, some questions had very small numbers of responses, and the authors were explicit in communicating the total number of participants when discussing responses to each question.

\section{Discussion}

In comparing survey sampling, Phillips and Atwood sent their survey to one librarian at each of the 72 OhioLINK institutions in their consortium..$^{58}$ Staines conducted data analysis by cross-tabulating library directors and instruction librarians to look for differing views (largely finding agreement across job titles)..$^{59} \mathrm{~A}$ unique aspect of the present study is sending the survey to more than one library employee identified as having job duties related to information literacy or outreach at large institutions. The richness of multiple perspectives from the same institution yields surprising results. Responses indicate confusion among colleagues at the same institution about what is offered institutionally and within the library for transfer students, specifically. Through data analysis, the authors identify institutional discrepancies based on individual librarian responses to the questions "Does your school have a designated transfer student orientation?" and "Is your library planning to create separate information literacy classes or workshops for transfer students?" This analysis indicates that library employees at the same college may not be aware of institutional or library priorities, initiatives, and programs for transfer students. This suggests that increased dialogue within as well as across institutions, and cross-functional training and awareness should become a priority. This finding may help explain why changes in professional practice have been slow-moving over the past three decades of research on this topic.

Placing the present survey in the context of prior findings, Staines' 1993 dissertation research advocated, "development of library instruction programs for transfer students needs to be created in light of trends in higher education that impact on the information literacy movement." 60 Such a statement would not be out of place in today's context, nearly three decades later. Several findings from this study align with findings from Staines, as well as Phillips and Atwood. New York and Colorado both indicate willingness to collaborate among two-year and four-year librarians, a hopeful theme. ${ }^{61}$ Yet, as in New York and Ohio, very few Colorado institutions currently teach information literacy classes, conduct outreach activities specifically for transfer students, or report plans to create these classes in the future. ${ }^{62}$ In 2010, Phillips and Atwood concluded, "despite the evidence in the literature, the same program deficiencies have continued suggesting that the needs of this population are not being addressed as a priority among Ohio academic libraries." ${ }^{63}$ Nearly a decade later, the authors of the present study are surprised to find that, for some questions, very little differs between Ohio and Colorado libraries.

Comparison shows a curious pendulum swing in library employee perceptions over time. Staines found that 89 percent of library employees answered "strongly agree or agree" when asked if there was a need for transfer student information literacy instruction. Phillips and Atwood found that no librarians replied "strongly agree," and only 13 percent of library professionals they surveyed responded "agree." The present study finds that 81 percent of library employees in Colorado report "strongly agree" or "agree." Such shifts may indicate fluctuations in awareness of transfer students and support for increased instruction and out- 
reach, though these positive perceptions are not currently demonstrated through activities for transfer students across the state of Colorado.

In terms of barriers to activities for transfer students, 82 percent of New York library employees listed funding and staffing to be barriers (reflecting a fiscal crisis within SUNY at the time) ${ }^{64}$ In Ohio, 54 percent of respondents had no specific reason for the lack of transfer student activities, though funding and staff issues (approximately 23\%), and the perception of few transfer students (approximately 12\%) were listed as the second and third largest barriers. ${ }^{65}$ This survey finds 50 percent of respondents have not considered offering transferspecific activities, with "other" concerns chosen by 37 percent and limited staffing chosen by 34.8 percent. Such overlap among Ohio and Colorado library professionals reflects the common challenges of many library organizations.

Staines found major differences between the information literacy teaching styles and practices of two-year and four-year libraries, reflective of changes in technology at the time, as well as an emphasis on tool-based instruction (two-year libraries) compared to conceptbased instruction emphasizing critical thinking skills (four-year libraries). ${ }^{66}$ Staines used this evidence to form an argument that library instruction for transfer students is especially important if students from two-year institutions are learning a set of "short-term" or "basic" information literacy skills compared to a perception of more adaptive skills taught to four-year students ${ }^{67}$ While the present study does not focus in depth on these pedagogical differences, table 5 shows that, in Colorado, the types of information literacy activities conducted differ across institution types. Such differences demonstrate differing priorities for two-year and four-year libraries that may be challenging to transfer students who are expected to have the same information literacy skills and knowledge as native students when arriving at four-year institutions. This argument supports the need for cross-institutional conversations that communicate expectations and transfer student-specific library instruction that both recognizes transfer students' prior library experiences and helps to build on their knowledge for the expectations at their new institution.

The authors find evidence of short-term and year-long transfer support services across various institutions in Colorado, such as peer mentor relationships, peer advisors, transfer welcome weeks, transfer student organizations, and university and college advisors. ${ }^{68}$ In another case, the authors note evidence of a bridge program, Bridges to Baccalaureate, a program funded by the National Institute of Health for transfer students from Front Range Community College to Colorado State University (CSU) that involves meetings with success coaches, workshops, and visits to CSU labs. ${ }^{69}$ However, these initiatives are not often sponsored by the library, nor are library personnel always aware of such programs.

\section{Conclusion}

By building on previous surveys of academic library employees in New York and Ohio, this article demonstrates an ongoing trend across 30 years of librarianship: transfer students have been and continue to be largely ignored as a distinct population by academic libraries. This article confirms the widespread nature of this issue across the country by adding results from a state in a new geographic region to existing literature. ${ }^{70}$ Additionally, this paper's analysis of multiple respondents from the same institution also demonstrates considerable discrepancies among colleagues. These discrepancies highlight differences between actual and perceived practices for transfer students, within their libraries as well as their institutions. 
Ultimately, both two-year and four-year librarians have opportunities to positively impact transfer students' experience, though they play different roles. Our results suggest that two-year librarians may not always recognize the role they can play in preparing transfer students with transferable skills and resources. Additionally, while not discussed by survey participants, two-year institutions in Colorado and throughout the United States do receive transfer students, though not typically at the rates of four-year institutions. Thus, two-year librarians are also on the receiving end for transfer students in addition to preparing students for four-year settings. Within Colorado's four-year institutions, there is a general assumption that a subject-specialist librarian is meeting the needs of transfer students without specific outreach or instruction to transfer students. This assumption stems from the fact that most transfer students begin their four-year career by transferring into a specific major and degree program. Addressing the specific needs of transfer students at four-year institutions, whether within discipline-specific contexts or generally through transfer student activities, is a worthwhile focus for four-year librarians. For both two-year and four-year libraries, crossinstitutional collaboration and strengthening of local networks may help ease transitions for transfer students.

Additional research is needed to understand student perspectives and library professionals' barriers. Since transfer student populations are often heterogeneous, more qualitative studies with transfer students are needed to better understand the complex interactions between transfer students' academic and social engagement. Information needs to be gathered generatively from students themselves, through both qualitative and quantitative studies. ${ }^{71}$ As Cutright acknowledges, many existing studies include questions with predetermined categories established by researchers instead of allowing students the opportunity to provide their experiences for researchers to analyze and induce new categories. ${ }^{72}$ Focus groups with academic librarians would provide deeper nuance for some of the trends identified through the CALTS study, in particular offering a deeper understanding of the barriers that prevent library professionals and academic libraries from offering transfer student-specific services. In addition to understanding transfer students better as a population, there is a need for libraryspecific studies that empirically test interventions and show the impact of library instruction on transfer student outcomes. 


\section{APPENDIX A. Colorado Academic Libraries Transfer Survey}

1. I agree to participate.

a. Yes, I agree

b. No, I don't agree

Condition: No, I don't agree Is Selected. Skip to: End of Survey.

2. With which higher education institution are you affiliated? Which best describes your institution?
a. 2-year institution
b. 4-year public institution
c. 4-year private institution

3. Please describe your current role in your library (choose only one):
a. Instruction Librarian
b. Outreach Librarian
c. Public Services Librarian
d. Library Administration
e. Other:

These next few questions will ask about your library's information literacy activities.

4. Does your library teach information literacy sessions? (For the purpose of our survey, information literacy encompasses bibliographic instruction, library instruction, tours, orientations, online instruction, and so on.)
a. Yes
b. No

5. What types of information literacy activities or techniques best describe your library's teaching efforts? Please check all that apply.

a. Individual appointments

b. Research guides (Web-based resources to which patrons can refer for research help.)

c. Handouts

d. Screencast videos (Explanatory videos to which patrons can refer for their research needs. These may highlight a resource, search technique, or more.)

e. Interactive online tutorials (Asynchronous, web-based interactive modules used to engage students with research strategies, library resources, or more.)

f. Virtual course integrated instruction (One or more synchronous instruction sessions taught through an online video conferencing platform and in coordination with a specific course and associated students.)

g. Face-to-face course-integrated instruction (One or more sessions held throughout the semester in coordination with a specific course and tied to a specific task, course assignment, course objective, or information literacy objective.)

h. Embedded course (Librarian is actively engaged in coplanning modules or sections of the course related to research and/or information literacy concepts. The librarian attends multiple sessions of the course, either in person or online. The librarian is not officially a teacher of record for the course.)

i. Librarian-led credit course (Librarian is either the instructor or co-teacher of a course.)

j. Orientation (Usually held at the beginning of a semester, an orientation is an overview session for a department, specific group of students, or faculty that provides 
a general introduction to services and collections but is not tied to a specific courserelated task or objective. Orientations may also include brief introductions or tours of physical spaces.)

k. Library tours (Held at various times throughout the year, a librarian or library staff member guides a group or individual through a specific library space highlighting services and collections. Select this option only if no additional instruction, training, or orientation occurred with the tour.)

1. Workshop (Not tied to a course. Held at various times throughout the semester, a workshop is a narrowly focused session [or more than one] but is not tied to a specific research task or course objective. Attendees may include a group of students, faculty, or the general public, such as Citing Sources 101 Workshop.)

m. Special events programming (Programming could include brief presentations to special populations and campus outreach programs.)

n. Assignment consultations with faculty (One-on-one consultations to plan course content, especially relating to the library, with faculty members.)

o. None of the above

p. Other:

6. How many information literacy sessions were taught by your library in the 2015-2016 academic year?
a. 0
b. $<25$
c. $25-50$
d. $51-100$
e. $10-150$
f. $151-200$
g. $201+$
h. Unsure

\begin{tabular}{|c|c|c|c|c|}
\hline $\begin{array}{l}\text { Please rate the degree to which these statements describe } \\
\text { the teaching of information literacy at your library. }\end{array}$ & $\begin{array}{l}\text { Strongly } \\
\text { Agree }\end{array}$ & Agree & Disagree & $\begin{array}{l}\text { Strongly } \\
\text { Disagree }\end{array}$ \\
\hline 7. Information literacy is integral to your library's mission. & & & & \\
\hline $\begin{array}{l}\text { 8. Information literacy is effective in teaching students how } \\
\text { to use library resources and services at your library. }\end{array}$ & & & & \\
\hline $\begin{array}{l}\text { 9. Information literacy is an effective use of budgetary } \\
\text { resources and staff time at your library. }\end{array}$ & & & & \\
\hline $\begin{array}{l}\text { 10. Information literacy sessions routinely make students } \\
\text { aware that resources are available at other academic } \\
\text { libraries across the state (such as EBSCO databases) }\end{array}$ & & & & \\
\hline $\begin{array}{l}\text { 11. Integrating library instruction for transfer students into } \\
\text { my information literacy sessions is difficult }\end{array}$ & & & & \\
\hline
\end{tabular}

The next few questions will ask specifically about your library's activities for transfer students.

12. Does your school have a designated transfer student orientation?
a. Yes
b. No
c. Unsure 
13. Does your library conduct outreach activities specifically for transfer students? (Please check all that apply.)

a. Library has a presence at New Student Orientation (which includes transfer students)

b. Library has a presence at specific student orientation for transfer students

c. Library offers a welcome activity for transfer students

d. Library has a designated employee who liaises with transfer students

e. Library collaborates with other departments on campus for transfer students

f. Other:

g. None of these

14. Does your library teach information literacy sessions specifically for transfer students?

a. Yes

b. No

15. How many information literacy sessions that are specifically targeted to transfer students does your library teach?

16. What types of information literacy activities or techniques best describe your library's teaching efforts for TRANSFER students? Please check all that apply.

a. Individual appointments

b. Research guides (Web-based resources to which patrons can refer for research help.)

c. Handouts

d. Screencast videos (Explanatory videos to which patrons can refer for their research needs. These may highlight a resource, search technique, or more.)

e. Interactive online tutorials (Asynchronous, web-based interactive modules used to engage students with research strategies, library resources, or more.)

f. Virtual course-integrated instruction (One or more synchronous instruction sessions taught through an online video conferencing platform and in coordination with a specific course and associated students.)

g. Face-to-face course-integrated instruction (One or more sessions held throughout the semester in coordination with a specific course and tied to a specific task, course assignment, course objective, or information literacy objective.)

h. Embedded course (Librarian is actively engaged in coplanning modules or sections of the course related to research and/or information literacy concepts. The librarian attends multiple sessions of the course, either in person or online. The librarian is not officially a teacher of record for the course.)

i. Librarian-led credit course (Librarian is either the instructor or co-teacher of a course.)

j. Orientation (Usually held at the beginning of a semester, an orientation is an overview session for a department, specific group of students, or faculty that provides a general introduction to services and collections but is not tied to a specific courserelated task or objective. Orientations may also include brief introductions or tours of physical spaces.)

k. Library tours (Held at various times throughout the year, a librarian or library staff member guides a group or individual through a specific library space highlighting services and collections. Select this option only if no additional instruction, training, or orientation occurred with the tour.)

1. Workshop (Not tied to a course. Held at various times throughout the semester, a workshop is a narrowly focused session [or more than one] but is not tied to a specific 
research task or course objective. Attendees may include a group of students, faculty, or the general public, such as Citing Sources 101 Workshop.)

m. Special events programming (Programming could include brief presentations to special populations and campus outreach programs.)

n. Assignment consultations with faculty (One-on-one consultations to plan course content, especially relating to the library, with faculty members.)

o. None of the above

p. Other:

17. What limitations prevent you from expanding the activities you host specifically for transfer students?
a. Limited staffing
b. Limited funding
c. Not enough transfer students enrolled
d. Unsuccessful attempts in the past
e. Transfer students are/perceived as already prepared
f. Other groups on campus have programming for transfer students
g. Hadn't considered offering more activities for transfer students
h. None of the above
i. Other:

18. Past efforts to provide information literacy sessions for transfer students have been successful.
a. Strongly agree
b. Agree
c. Disagree
d. Strongly disagree

19. Is your library planning to create separate information literacy classes or workshops for transfer students?
a. Yes
b. No
c. Unsure

Display This Question:

If Is your library planning to create separate information literacy classes or workshops for transfer students?

Or Is your library planning to create separate information literacy classes or workshops for transfer students?

20. Which of these prevent you from offering activities specifically for transfer students? Please check all that apply.
a. Limited staffing
b. Limited funding
c. Not enough transfer students enrolled
d. Unsuccessful attempts in the past
e. Transfer students are/perceived as already prepared 
f. Other groups on campus have programming for transfer students

g. Hadn't considered offering activities for transfer students

h. None of the above

i. Other:

Please indicate the extent to which you agree with the following:

\begin{tabular}{|c|c|c|c|c|}
\hline $\begin{array}{l}\text { Please indicate the extent to which you agree with the } \\
\text { following: }\end{array}$ & $\begin{array}{c}\text { Strongly } \\
\text { Agree }\end{array}$ & Agree & Disagree & $\begin{array}{l}\text { Strongly } \\
\text { Disagree }\end{array}$ \\
\hline \multicolumn{5}{|l|}{$\begin{array}{l}\text { 21. The transfer student population at my institution is large } \\
\text { enough to necessitate information literacy classes to be } \\
\text { held specifically for them. }\end{array}$} \\
\hline \multicolumn{5}{|l|}{$\begin{array}{l}\text { 22. My library is adequately staffed to teach information } \\
\text { literacy skills to transfer students. }\end{array}$} \\
\hline \multicolumn{5}{|l|}{$\begin{array}{l}\text { 23. There is a need for transfer student information literacy } \\
\text { instruction. }\end{array}$} \\
\hline \multicolumn{5}{|l|}{$\begin{array}{l}\text { 24. Information literacy sessions should be scaffolded across } \\
\text { two-year and four-year institutions, moving from basic to } \\
\text { more advanced concepts. }\end{array}$} \\
\hline \multicolumn{5}{|l|}{$\begin{array}{l}\text { 25. Students should be able to transfer their library research } \\
\text { skills from one academic library to another. }\end{array}$} \\
\hline $\begin{array}{l}\text { Please indicate the extent to which you agree with the } \\
\text { following: }\end{array}$ & \begin{tabular}{c|}
$\begin{array}{c}\text { Strongly } \\
\text { Agree }\end{array}$ \\
\end{tabular} & Agree & Disagree & $\begin{array}{l}\text { Strongly } \\
\text { Disagree }\end{array}$ \\
\hline \multicolumn{5}{|l|}{$\begin{array}{l}\text { 26. Students at my institution are routinely taught that } \\
\text { many library skills they acquire are transferable to other } \\
\text { academic libraries. }\end{array}$} \\
\hline \multicolumn{5}{|l|}{$\begin{array}{l}\text { 27. Transfer student needs differ from the needs of students } \\
\text { who started as freshmen at my institution. }\end{array}$} \\
\hline \multicolumn{5}{|l|}{$\begin{array}{l}\text { 28. Information literacy sessions should focus on teaching } \\
\text { students about the array of services and resources in my } \\
\text { library, not about resources at other public or academic } \\
\text { libraries in the area. }\end{array}$} \\
\hline \multicolumn{5}{|l|}{$\begin{array}{l}\text { 29. Students at my institution routinely use resources that can } \\
\text { be found at other academic libraries throughout the state } \\
\text { (such as EBSCO databases). }\end{array}$} \\
\hline \multicolumn{5}{|l|}{$\begin{array}{l}\text { 30. There is a shared responsibility among all academic } \\
\text { libraries within Colorado to teach library research skills to } \\
\text { transfer students. }\end{array}$} \\
\hline $\begin{array}{l}\text { Please indicate the extent to which you agree with the } \\
\text { following: }\end{array}$ & \begin{tabular}{|c|}
$\begin{array}{c}\text { Strongly } \\
\text { Agree }\end{array}$ \\
\end{tabular} & Agree & Disagree & $\begin{array}{l}\text { Strongly } \\
\text { Disagree }\end{array}$ \\
\hline \multicolumn{5}{|l|}{$\begin{array}{l}\text { 31. Community college libraries have the sole responsibility of } \\
\text { teaching library research skills to transfer students. }\end{array}$} \\
\hline $\begin{array}{l}\text { 32. Cooperation among academic libraries' information } \\
\text { literacy programs helps transfer students succeed } \\
\text { academically. }\end{array}$ & & & & \\
\hline
\end{tabular}

33. Is there anything you think we should know about transfer students and your library? 


\begin{tabular}{|l|l|l|l|}
\hline $\begin{array}{l}\text { Please let us know if you would be interested in any of } \\
\text { the following: }\end{array}$ & Yes & Maybe & No \\
\hline $\begin{array}{l}\text { 34. Would you be interested in working with other two- } \\
\text { year and four-year academic libraries in Colorado on } \\
\text { programming for transfer students? }\end{array}$ & & & \\
\hline $\begin{array}{l}\text { 35. Are you willing to participate in future interviews } \\
\text { about transfer students and your academic library? }\end{array}$ & & & \\
\hline 36. Would you like to receive the results of the research? & & & \\
\hline
\end{tabular}

Display This Question:

If Please let us know if you would be interested in any of the following: Would you be interested in working with other two-year and four-year academic libraries in Colorado on programming for transfer students?

Or Please let us know if you would be interested in any of the following: Would you be interested in working with other two-year and four-year academic libraries in Colorado on programming for transfer students?

Or Please let us know if you would be interested in any of the following: Are you willing to participate in future interviews about transfer students and your academic library?

Or Please let us know if you would be interested in any of the following: Are you willing to participate in future interviews about transfer students and your academic library?

Or Please let us know if you would be interested in any of the following: Would you like to receive the results of the research?

Or Please let us know if you would be interested in any of the following: Would you like to receive the results of the research?

Thanks for your interest in future follow-up! Please provide your email address:

\section{Notes}

1. Susan Choy, "Findings from the Condition of Education 2002: Nontraditional Undergraduates (NCES 2002-012)" (National Center for Education Statistics, U.S. Department of Education, 2002), available online at http://eric.ed.gov/?id=ED471077 [accessed 2 August 2017].

2. Katharin Peter and Emily Forrest Cataldi, "The Road Less Traveled? Students Who Enroll in Multiple Institutions: Postsecondary Education Descriptive Analysis Report (NCES 2005-157)" (National Center for Education Statistics, U.S. Department of Education, 2005), 34, available online at http://eric.ed.gov/?id=ED492633 [accessed 10 June 2017].

3. Sean Anthony Simone, "Transferability of Postsecondary Credit Following Student Transfer or Coenrollment: Statistical Analysis Report (NCES 2014-163)" (National Center for Education Statistics, U.S. Department of Education), iv, available online at https://nces.ed.gov/pubs2014/2014163.pdf [accessed 23 August 2017].

4. The Condition of Education 2017 (NCES 2017-144) (Washington, DC: National Center for Education Statistics, U.S. Department of Education, May 2017), 120.

5. American Library Association, "Library Bill of Rights" (1996), available online at www.ala.org/advocacy/ intfreedom/librarybill [accessed 23 August 2017]; American Library Association, "Professional Ethics" (2008), available online at www.ala.org/tools/ethics [accessed 23 August 2017]; Jolanta Juszkiewicz, "Trends in Community College Enrollment and Completion Data, 2015," American Association of Community Colleges (2015), avail- 
able online at https://eric.ed.gov/?id=ED557990 [accessed 23 August 2017]; "Advancing Diversity and Inclusion in Higher Education: Key Data Highlights Focusing on Race and Ethnicity and Promising Practices" (Office of Planning, Evaluation, and Policy Development, U.S. Department of Education, November 2016), available online at https://www2.ed.gov/rschstat/research/pubs/advancing-diversity-inclusion.pdf [accessed 23 August 2017].

6. Association of College and Research Libraries, "Academic Library Impact on Student Learning and Success: Findings from the Assessment in Action Team Projects" (Chicago: Association of College and Research Libraries, April 2017), available online at www.ala.org/acrl/sites/ala.org.acrl/files/content/issues/value/findings_y3.pdf [accessed 20 July 2017]; Silas M. Oliveira, “The Academic Library's Role in Student Retention: A Review of the Literature," Library Review 66, no. 4/5 (July 4, 2017): 310-29, doi:10.1108/LR-12-2016-0102.

7. Barbara K. Townsend, "Transfer Rates: A Problematic Criterion for Measuring the Community College," New Directions for Community Colleges 117 (2002): 20, doi:10.1002/cc.49.

8. Peter and Cataldi, “The Road Less Traveled?" iii.

9. Townsend, "Transfer Rates: A Problematic Criterion for Measuring the Community College," 13.

10. Gretchen Warner Kearney, Barbara K. Townsend, and Terrence J. Kearney, "Multiple-Transfer Students in a Public Urban University: Background Characteristics and Interinstitutional Movements," Research in Higher Education 36, no. 3 (June 1, 1995): 339, doi:10.1007/BF02208314.

11. Jolanta Juszkiewicz, "Trends in Community College Enrollment and Completion Data" (Washington, DC: American Association of Community Colleges, 2017), 5, available online at https://www.aacc.nche.edu/ wp-content/uploads/2017/11/TrendsCCEnrollment_Final2016.pdf [accessed 15 December 2017].

12. Juszkiewicz, "Trends in Community College Enrollment and Completion Data," 5; Integrated Postsecondary Education Data System, National Center for Education Statistics, U.S. Department of Education, "IPEDS Survey Components: Outcome Measures Survey Changes" (Washington, DC, 2017), available online at https:// nces.ed.gov/ipeds/InsidePages/SurveyComponent/outcome-measures [accessed 26 December 2017].

13. Vincent Tinto, "Dropout from Higher Education: A Theoretical Synthesis of Recent Research," Review of Educational Research 45, no. 1 (1975): 111; Vincent Tinto, Completing College: Rethinking Institutional Action (Chicago, IL: The University of Chicago Press, 2012), vii; Mark M. D'Amico et al., “Early Integration and Other Outcomes for Community College Transfer Students," Research in Higher Education 55, no. 4 (June 2014): 370-99, doi:10.1007/ s11162-013-9316-5.

14. Tinto, "Dropout from Higher Education," 117.

15. Ernest T. Pascarella, Patrick T. Terenzini, and Lee M. Wolfle, "Orientation to College and Freshman Year Persistence/Withdrawal Decisions," Journal of Higher Education 57, no. 2 (Mar. 1, 1986): 155-75, doi:10.1080/00221 546.1986.11778760; Trudy H. Bers and Kerry E. Smith, "Persistence of Community College Students: The Influence of Student Intent and Academic and Social Integration," Research in Higher Education 32, no. 5 (1991): 539-56; D’Amico et al., "Early Integration and Other Outcomes for Community College Transfer Students."

16. Linda Serra Hagedorn, Scott Cypers, and Jaime Lester, "Looking in the Review Mirror: Factors Affecting Transfer for Urban Community College Students," Community College Journal of Research and Practice 32, no. 9 (Aug. 5, 2008): 643-64, doi:10.1080/10668920802026113; D'Amico et al., “Early Integration and Other Outcomes for Community College Transfer Students"; Marc Cutright, "The Changing Nature of Today's Transfer Students," in Transfer Students in Higher Education: Building Foundations for Policies, Programs, and Services That Foster Student Success, eds. Mark Allen Poisel and Sonya Joseph, The First-Year Experience Monograph Series (Columbia, SC: National Resource Center for The First Year Experience, University of South Carolina, 2011), 1-11.

17. John R. Hills, "Transfer Shock: The Academic Performance of the Junior College Transfer," Journal of Experimental Education 33, no. 3 (Mar. 1965): 201-15, doi:10.1080/00220973.1965.11010875; Sharon Paterson McGuire and Marcia Belcheir, "Transfer Student Characteristics Matter," Journal of College Student Retention: Research, Theory E Practice 15, no. 1 (May 2013): 37-48, doi:10.2190/CS.15.1.c; Cutright, "The Changing Nature of Today's Transfer Students"; Tammy J. Rhine, Dawna M. Milligan, and Lynne R. Nelson, "Alleviating Transfer Shock: Creating an Environment for More Successful Transfer Students," Community College Journal of Research and Practice 24, no. 6 (July 1, 2000): 443-53, doi:10.1080/10668920050137228.

18. Cutright, "The Changing Nature of Today's Transfer Students," 3.

19. Frankie Santos Laanan, Soko S. Starobin, and Latrice E. Eggleston, "Adjustment of Community College Students at a Four-Year University: Role and Relevance of Transfer Student Capital for Student Retention," Journal of College Student Retention: Research, Theory \& Practice 12, no. 2 (Aug. 2010): 179, doi:10.2190/CS.12.2.d.

20. Gloria Crisp and Anne-Marie Nuñez, "Understanding the Racial Transfer Gap: Modeling Underrepresented Minority and Nonminority Students' Pathways from Two-to Four-Year Institutions," Review of Higher Education 37, no. 3 (2014): 291-320, doi:10.1353/rhe.2014.0017.

21. McGuire and Belcheir, "Transfer Student Characteristics Matter," 41.

22. Lovenoor Aulck and Jevin West, "Attrition and Performance of Community College Transfers," PLOS 
ONE 12, no. 4 (Apr. 13, 2017): 11, doi:10.1371/journal.pone.0174683.

23. Hagedorn, Cypers, and Lester, "Looking in the Review Mirror," 661.

24. Association of College and Research Libraries, "Academic Library Impact on Student Learning and Success."

25. Association of College and Research Libraries, 2.

26. Oliveira, "The Academic Library's Role in Student Retention," 310.

27. Gail M. Staines, "Moving beyond Institutional Boundaries: Perceptions toward BI among Transfer Students," Research Strategies 14, no. 2 (1996): 93-107; John C. Phillips and Thomas A. Atwood, "Transferring Skills, Transferring Students: A Call to Academic Libraries," College \& Undergraduate Libraries 17, no. 4 (Oct. 2010): 331-48.

28. Phillips and Atwood, "Transferring Skills, Transferring Students," 332, doi:10.1080/10691316.2010.525394.

29. Staines, "Moving beyond Institutional Boundaries," 96; Jennifer Cox and Ralph Johnson, "Transfer Students in the Library: The Forgotten Population," Research Strategies 10, no. 2 (1992): 88-91.

30. Kelly C. McCallister, Margaret N. Gregor, and Deborah W. Joyner, "Librarians Collaborate! Working Across Two-and Four-Year Institutions to Teach Information Literacy Skills" (ACRL, March 25-28, Portland, OR, 2015), 437, available online at www.ala.org/acrl/sites/ala.org.acrl/files/content/conferences/confsandpreconfs/2015/ McCallister_Gregor_Joyner.pdf [accessed 20 December 2017]; Phillips and Atwood, "Transferring Skills, Transferring Students."

31. Elizabeth W. Kraemer, Dana J. Keyse, and Shawn V. Lombardo, “Beyond These Walls: Building a Library Outreach Program at Oakland University," Reference Librarian 39, no. 82 (Sept. 2003 ): 7.

32. Sharon Bostick, The Development and Validation of the Library Anxiety Scale (Detroit, MI: Wayne State University, 1992), 84; Constance A. Mellon, "Library Anxiety: A Grounded Theory and Its Development," College E Research Libraries 47, no. 2 (1986): 160-64; Kraemer, Keyse, and Lombardo, "Beyond These Walls: Building a Library Outreach Program at Oakland University," 8.

33. Cox and Johnson, "Transfer Students in the Library: The Forgotten Population," 88; Julie Still, "Library Services for Transfer Students," Community and Junior College Libraries 7, no. 1 (1990): 52.

34. Staines, "Moving beyond Institutional Boundaries," 94.

35. Bostick, The Development and Validation of the Library Anxiety Scale, 84; Qun G. Jiao and Anthony J. Onwuegbuzie, "Antecedents of Library Anxiety," Library Quarterly: Information, Community, Policy 67, no. 4 (1997): 385.

36. Mellon, "Library Anxiety"; Bostick, The Development and Validation of the Library Anxiety Scale.

37. Sylvia G. Tag, "A Library Instruction Survey for Transfer Students: Implications for Library Services," Journal of Academic Librarianship 30, no. 2 (Mar. 2004): 102-08.

38. Tag, "A Library Instruction Survey for Transfer Students," 105-06.

39. Phillips and Atwood, "Transferring Skills, Transferring Students," 340.

40. Phillips and Atwood, "Transferring Skills, Transferring Students," 342-43.

41. Phillips and Atwood, "Transferring Skills, Transferring Students," 343.

42. McCallister, Gregor, and Joyner, "Librarians Collaborate!"

43. Staines, "Moving beyond Institutional Boundaries."

44. Staines, "Moving beyond Institutional Boundaries."

45. Phillips and Atwood, "Transferring Skills, Transferring Students," 338.

46. Phillips and Atwood, Transferring Skills, Transferring Students," 332.

47. Phillips and Atwood, "Transferring Skills, Transferring Students"; Cox and Johnson, "Transfer Students in the Library: The Forgotten Population"; Staines, "Moving beyond Institutional Boundaries"; Roberta L. Tipton and Patricia Bender, "From Failure to Success: Working with Underprepared Transfer Students," Reference Services Review 34, no. 3 (Aug. 2006): 389-404; McCallister, Gregor, and Joyner, "Librarians Collaborate!"

48. Kraemer, Keyse, and Lombardo, "Beyond These Walls."

49. Ibid.

50. Ibid.

51. Staines, "Applying Perceptions of Library Instruction Librarians and Library Directors"; Phillips and Atwood, "Transferring Skills, Transferring Students."

52. Michael J. Firmin, "Replication," in The SAGE Encyclopedia of Qualitative Research Methods, ed. Lisa Given (Thousand Oaks, CA: SAGE Publications, Inc., 2008), doi:10.4135/9781412963909.n381.

53. Instruction Working Group and University of Colorado Boulder, "Instruction Activity Definitions \& Descriptions" (2013), available online at https://docs.google.com/a/colorado.edu/document/d/1ESfoP_hcvLjMJdJ9JkbvkjtZtQodipaJKAQGJ6E4oTE/pub [accessed 6 February 2018].

54. Division of Research and Planning, Colorado Department of Higher Education, "Transfer (At Entry) Summary FY2014-15" (2016), available online at http://highered.colorado.gov/Publications/Reports/Enrollment/ 
FY2015/2015_Transfer_Summary.pdf [accessed 1 September 2017].

55. Division of Research and Planning, Colorado Department of Higher Education, "Transfer (At Entry) Summary FY2014-15."

56. Division of Research and Planning, Colorado Department of Higher Education, "Transfer (At Entry) Summary FY2014-15."

57. Division of Research and Planning, Colorado Department of Higher Education, "Transfer (At Entry) Summary FY2014-15."

58. Phillips and Atwood, "Transferring Skills, Transferring Students," 338.

59. Staines, "Moving beyond Institutional Boundaries."

60. Staines, "Moving beyond Institutional Boundaries," 178.

61. Staines, "Moving beyond Institutional Boundaries," 177.

62. Phillips and Atwood, "Transferring Skills, Transferring Students," 341-42; Staines, "Moving beyond Institutional Boundaries," 167-68.

63. Phillips and Atwood, "Transferring Skills, Transferring Students," 340.

64. Staines, "Moving beyond Institutional Boundaries," 80-81.

65. Phillips and Atwood, "Transferring Skills, Transferring Students," 340.

66. Staines, "Moving beyond Institutional Boundaries," 116-26.

67. Staines, "Moving beyond Institutional Boundaries," 128.

68. Academic Advising Center College of Arts \& Sciences, University of Colorado Boulder, "CU Thrive," available online at www.colorado.edu/advising/resources-support/resource-center/cu-thrive [accessed 1 September 2017]; Discoveries Orientation, University of Denver, "2017 Transfer Welcome Week Schedule," available online at https://www.du.edu/studentlife/discoveries/media/documents/2017_transferwelcomeweek_webversion.pdf [accessed 1 September 2017]; Support and Outreach, University of Denver, "Transfer Students," available online at https://www.du.edu/studentlife/studentsupport/support_outreach/transfers.html [accessed 1 September 2017].

69. Front Range Community College, "Bridges to Baccalaureate Transfer," available online at https://www. frontrange.edu/graduation-and-beyond/transfer-out/transfer-degrees/bridges-to-baccalaureate-transfer [accessed 18 December 2017].

70. Staines, "Moving beyond Institutional Boundaries"; Phillips and Atwood, "Transferring Skills, Transferring Students."

71. Jaime Lester, Jeannie Brown Leonard, and David Mathias, "Transfer Student Engagement: Blurring of Social and Academic Engagement," Community College Review 41, no. 3 (2013): 202-22; Barbara K. Townsend and Kristin B. Wilson, "The Academic and Social Integration of Persisting Community College Transfer Students," Journal of College Student Retention: Research, Theory \& Practice 10, no. 4 (Feb. 2009): 405-23, doi:10.2190/CS.10.4.a.

72. Cutright, "The Changing Nature of Today's Transfer Students." 